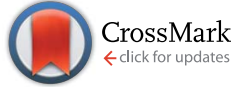

Cite this: J. Mater. Chem. C, 2015, 3, 423

Received 15th October 2014

Accepted 6th November 2014

DOI: $10.1039 / \mathrm{c} 4 \mathrm{tc} 02327 \mathrm{~g}$

www.rsc.org/MaterialsC

\section{Chemical vapour deposition of antimony chalcogenides with positional and orientational control: precursor design and substrate selectivity $\dagger$}

\author{
S. L. Benjamin, ${ }^{a}$ C. H. de Groot, ${ }^{\text {b A. L. Hector, }}{ }^{\text {a }}$ R. Huang, ${ }^{\text {b }}$ E. Koukharenko, ${ }^{\text {b }}$ \\ W. Levason ${ }^{a}$ and G. Reid*a
}

\begin{abstract}
A series of alkylchalcogenostibines, $\mathrm{Me}_{2} \mathrm{SbSe}{ }^{n} \mathrm{Bu}, \mathrm{MeSb}\left(\mathrm{Se}^{n} \mathrm{Bu}\right)_{2}, \mathrm{Sb}\left(\mathrm{Se}{ }^{n} \mathrm{Bu}\right)_{3}$ and $\mathrm{MeSb}\left(\mathrm{Te} e^{n} \mathrm{Bu}\right)_{2}$, have been designed and synthesised as potential precursors for chemical vapour deposition (CVD) by reaction of ${ }^{n} \mathrm{BuELi}(\mathrm{E}=\mathrm{Se}, \mathrm{Te})$ with the appropriate halostibine, $\mathrm{Me}_{3-n} \mathrm{SbCl}_{n}(n=1,2,3)$, and characterised by ${ }^{1} \mathrm{H}$, ${ }^{13} \mathrm{C}\left\{{ }^{1} \mathrm{H}\right\}$ and ${ }^{77} \mathrm{Se}\left\{{ }^{1} \mathrm{H}\right\}$ or ${ }^{125} \mathrm{Te}\left\{{ }^{1} \mathrm{H}\right\}$ NMR spectroscopy as appropriate. MeSb $\left(\mathrm{Se}^{n} \mathrm{Bu}\right)_{2}$ and $\mathrm{MeSb}\left(\mathrm{Te}{ }^{n} \mathrm{Bu}\right)_{2}$ are very effective single source precursors for the low pressure CVD of high quality crystalline thin films of $\mathrm{Sb}_{2} \mathrm{Se}_{3}$ and $\mathrm{Sb}_{2} \mathrm{Te}_{3}$, respectively, confirmed by scanning electron microscopy, energy dispersive $\mathrm{X}$-ray spectroscopy, Raman spectroscopy and thin film X-ray diffraction. Hall conductivity, carrier mobility, carrier density and, in the case of $\mathrm{Sb}_{2} \mathrm{Te}_{3}$, Seebeck coefficient measurements reveal electronic characteristics comparable with $\mathrm{Sb}_{2} \mathrm{E}_{3}$ deposited by atomic layer deposition or molecular beam epitaxy, suggesting materials quality and performance suitable for incorporation into electronic device structures. Choice of substrate and deposition conditions were found to significantly affect the morphology and preferred orientation of $\mathrm{Sb}_{2} \mathrm{Te}_{3}$ crystallites, enabling deposition of films with either $\left\langle\begin{array}{lllllll}1 & 1 & 0\end{array}\right\rangle$ or $\left\langle\begin{array}{llll}0 & 0 & 1\end{array}\right\rangle$ alignment. Use of micro-patterned substrates allowed selective deposition of crystalline 2D micro-arrays of $\mathrm{Sb}_{2} \mathrm{Te}_{3}$ onto exposed TiN surfaces only.
\end{abstract}

\section{Introduction}

Antimony chalcogenides $\mathrm{Sb}_{2} \mathrm{E}_{3}(\mathrm{E}=\mathrm{Se}, \mathrm{Te})$ are versatile semiconductor materials with narrow bandgaps, which are increasingly demonstrating potential in a diversity of microelectronic applications, especially in low dimensional forms. The most established of these is as thermoelectric materials with moderate figures of merit $(Z T)$, often combined with $\mathrm{Bi}_{2} \mathrm{E}_{3}$ in thermoelectric devices for near room temperature applications. ${ }^{1}$ Thermoelectrics have the potential to provide a source of sustainable, emission-free energy or cooling, but advances are required to improve current material efficiencies. Controlling the dimensionality in such materials can lead to significant improvements in $Z T,{ }^{2}$ and superlattices of $\mathrm{Sb}_{2} \mathrm{Te}_{3}$ and $\mathrm{Bi}_{2} \mathrm{Te}_{3}$ have been claimed to have among the highest $Z T$ values ever recorded. ${ }^{3}$ Anisotropy of the thermal and electrical parameters in the layered lattice structures of these materials means that control over crystallite orientation offers another route to maximise $Z T^{4-6}$ In addition, $\mathrm{Sb}_{2} \mathrm{Te}_{3}$ is a topological insulator,

${ }^{a}$ Chemistry, University of Southampton, SO17 1BJ, UK. E-mail: G.Reid@soton.ac.uk ${ }^{b}$ Electronics and Computer Science, University of Southampton, SO17 1BJ, UK

$\dagger$ Electronic supplementary information (ESI) available: TGA of $\mathrm{MeSb}\left(\mathrm{Te}^{n} \mathrm{Bu}\right)_{2}$, EDX spectra of $\mathrm{Sb}_{2} \mathrm{Te}_{3}$ and $\mathrm{Sb}_{2} \mathrm{Te}_{3}$ thin films, XRD pattern for $\mathrm{Sb}_{2} \mathrm{Te}_{3}$ deposited onto PVD silica substrates, lattice parameters calculated from XRD data. See DOI: $10.1039 / \mathrm{c} 4 \mathrm{tc} 02327 \mathrm{~g}$ with potential applications in quantum computing. ${ }^{7}$ Exploitation of this effect requires single crystals of the binary material; confinement to the nanoscale maximises the surface to volume ratio, preventing topological surface states from being dominated by bulk conduction states. ${ }^{8}$ Finally, $\mathrm{Sb}_{2} \mathrm{Se}_{3}$ has received considerable recent attention as an efficient light sensitiser, which can be incorporated as a thin film into multilayer photovoltaic devices., ${ }^{\mathbf{9} 10}$

Chemical vapour deposition (CVD) is a technique widely used industrially to deposit thin films of a range of materials, including binary semiconductors, due to the scalable and costeffective nature of the process. The potential of employing CVD as an effective route to low dimensional $\mathrm{Sb}_{2} \mathrm{E}_{3}$ has been little explored. One very recent approach employs ${ }^{\mathrm{i}} \mathrm{Pr}_{3} \mathrm{Sb}$ and $\mathrm{Et}_{2} \mathrm{Te}_{2}$ as dual source precursors for the metal-organic (MO) CVD of flat films of $\mathrm{Sb}_{2} \mathrm{Te}_{3} \cdot{ }^{11}$ Single source precursors (SSPs) are a promising alternative for these systems, as they improve ease of handling and atom efficiency while allowing properties such as stoichiometry and morphology to be directed by precursor design. ${ }^{12,13}$ There are very few examples of the use of SSPs for the deposition of $\mathrm{Sb}_{2} \mathrm{E}_{3}$. Individual $\mathrm{Sb}_{2} \mathrm{Te}_{3}$ nanoplates and $\mathrm{Sb}_{2} \mathrm{Se}_{3}$ nanorods have been synthesised by aerosol assisted (AA) CVD from $\left[\mathrm{Sb}\left\{\left(\mathrm{TeP}^{\mathrm{i}} \mathrm{Pr}_{2}\right)_{2} \mathrm{~N}\right\}_{3}\right]$ and $\left[\mathrm{Sb}\left\{\mathrm{SeC}_{5} \mathrm{H}_{3}(\mathrm{Me}-3) \mathrm{N}\right\}_{3}\right]$ respectively, the latter being a very rare example of the preparation of $\mathrm{Sb}_{2} \mathrm{Se}_{3}$ by CVD. ${ }^{\mathbf{1 4 , 1 5}}$ Preliminary investigations into the use of the organometallic species $\mathrm{Et}_{2} \mathrm{SbTeEt}$ and $\mathrm{Te}\left(\mathrm{SbEt}_{2}\right)_{2}$ as SSPs in 
AACVD did not yield stoichiometric $\mathrm{Sb}_{2} \mathrm{Te}_{3} \cdot{ }^{16}$ However, $\mathrm{Te}\left(\mathrm{SbEt}_{2}\right)_{2}$ was employed successfully as a SSP in the synthesis of $\mathrm{Sb}_{2} \mathrm{Te}_{3}$ nanoplates by thermal decomposition methods, ${ }^{17}$ and recent studies have shown that CVD from the same precursor gives poorly aggregated $\mathrm{Sb}_{2} \mathrm{Te}_{3}$ films at $200{ }^{\circ} \mathrm{C}$, with antimonyrich films being obtained at higher temperatures. ${ }^{18}$

We have previously developed systems for low pressure (LP) CVD of metal chalcogenide thin films from coordination complexes with neutral chalcogenoether ligands. ${ }^{19-22}$ In these systems we found that precursors containing $-\mathrm{E}^{n} \mathrm{Bu}$ groups $(\mathrm{E}=$ $\mathrm{Se}, \mathrm{Te}$ ) out-perform those with shorter alkyl or aryl groups at the chalcogen, giving uniform thin films of high quality. Coordination complexes of heavy p-block metals with chalcogen containing ligands have some potential disadvantages when considered as precursors for LPCVD, namely their relatively low volatilities, resulting in short deposition path lengths and reduced atom efficiency, and the presence of halides or other elements which in some circumstances can act as undesirable contaminants, severely diminishing electronic performance. Organometallic species containing bonds between p-block elements with only hydrocarbon substituents present a potential solution to these challenges.

As a result of these considerations, we identified compounds of the form $\mathrm{R}_{3-n} \mathrm{Sb}\left(\mathrm{E}^{n} \mathrm{Bu}\right)_{n}$ for development as improved precursors for LPCVD. Here we report the synthesis of a new series of these compounds and their employment for the CVD of high quality, uniform, polycrystalline $\mathrm{Sb}_{2} \mathrm{E}_{3}$ thin films. Modifications in precursor design allow optimisation of stoichiometry and coverage, while variations in substrate and temperature give remarkable control over film morphology and crystallite orientation, including fabrication of micro-scale arrays.

\section{Results and discussion}

\section{Synthesis of tailored single source precursors}

The selenostibines, $\mathrm{Me}_{2} \mathrm{SbSe}^{n} \mathrm{Bu}, \mathrm{MeSb}\left(\mathrm{Se}^{n} \mathrm{Bu}\right)_{2}$ and $\mathrm{Sb}\left(\mathrm{Se}^{n} \mathrm{Bu}\right)_{3}$, were prepared by generating ${ }^{n} \mathrm{BuSeLi}$ in situ ${ }^{23}$ and reacting this with the appropriate chlorostibine (Scheme 1).

Molecules of the type $\mathrm{R}_{2} \mathrm{SbSeR}^{\prime}\left(\mathrm{R}=\mathrm{Me}, \mathrm{Et} ; \mathrm{R}^{\prime}=\mathrm{Me}, \mathrm{Ph}\right)$ have previously been synthesised by the comproportionation of $\mathrm{R}_{2} \mathrm{SbSbR}_{2}$ with $\mathrm{R}^{\prime} \operatorname{SeSeR}^{\prime},{ }^{24,25}$ and one structure $\left(\mathrm{R}=\mathrm{R}^{\prime}=\mathrm{Me}\right)$ has been determined by gas phase electron diffraction. ${ }^{26}$ Heating of these compounds over a period of hours gives $\mathrm{RSb}\left(\mathrm{SeR}^{\prime}\right)_{2}$ and $\mathrm{SbR}_{3}{ }^{27}$ The only previously reported species of the form $\mathrm{Sb}(\mathrm{SeR})_{3}(\mathrm{R}=$ alkyl $)$ is $\mathrm{Sb}(\mathrm{SeMe})_{3}$, which was synthesised by reflux of elemental $\mathrm{Sb}$ with $\mathrm{Me}_{2} \mathrm{Se}_{2}$ in toluene. The crystal structure shows the presence of weak intermolecular $\mathrm{Sb} \cdots \mathrm{Se}$ contacts which form a $2 \mathrm{D}$ sheet. ${ }^{28}$

The three new selenostibines with varying $\mathrm{Sb}: \mathrm{Se}$ ratios (1:1, $1: 2$ and $1: 3$ ) were tested as precursors for the LPCVD of $\mathrm{Sb}_{2} \mathrm{Se}_{3}$ under varying conditions. All three precursors deposited grey thin films onto fused $\mathrm{SiO}_{2}$ substrates at $500{ }^{\circ} \mathrm{C}$, which were observed by scanning electron microscopy (SEM) to be composed of rod-like crystallites. Energy dispersive X-ray spectroscopy (EDX) demonstrated that both Sb and Se were present in all films, however those deposited from $\mathrm{Me}_{2} \mathrm{SbSe}^{n} \mathrm{Bu}$ had a variable $\mathrm{Sb}: \mathrm{Se}$ ratio which was generally high in $\mathrm{Sb}$ (around

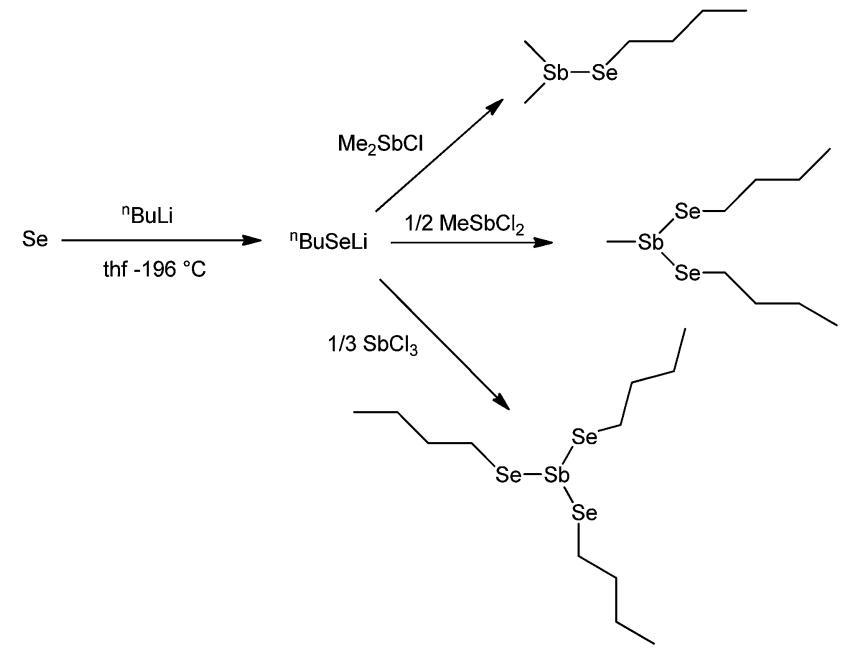

Scheme 1 Synthesis of alkylselenostibines.

1:1), whereas those deposited from $\mathrm{MeSb}\left(\mathrm{Se}^{n} \mathrm{Bu}\right)_{2}$ and $\mathrm{Sb}\left(\mathrm{Se}^{n} \mathrm{Bu}\right)_{3}$ had $\mathrm{Sb}: \mathrm{Se}$ ratios close to the desired $1: 1.5$. Of these, $\mathrm{MeSb}\left(\mathrm{Se}^{n} \mathrm{Bu}\right)_{2}$ gave films of consistently superior uniformity and coverage, probably due to its higher volatility, and as a result this was the precursor selected for further study (vide infra). These results demonstrate how stoichiometry and morphology of thin films deposited by CVD can be manipulated by the modification of single source precursor design.

Given the identification of $\mathrm{MeSb}\left(\mathrm{Se}^{n} \mathrm{Bu}\right)_{2}$ as the most effective precursor for the CVD of $\mathrm{Sb}_{2} \mathrm{Se}_{3}$, the analogous tellurostibine, $\mathrm{MeSb}\left(\mathrm{Te}^{n} \mathrm{Bu}\right)_{2}$, was targeted as the precursor of choice for the CVD of $\mathrm{Sb}_{2} \mathrm{Te}_{3}$. It was prepared by the addition of $0.5 \mathrm{~mol}$. equiv. of $\mathrm{MeSbCl}_{2}$ to a freshly prepared solution of ${ }^{n} \mathrm{BuTeLi}^{29}$ at $-78{ }^{\circ} \mathrm{C}$ (Scheme 2).

The ${ }^{1} \mathrm{H}$ NMR spectrum shows a singlet corresponding to the MeSb group, with four multiplets corresponding to the ${ }^{n} \mathrm{BuTe}$ groups, in the expected ratios, and a singlet evident in the ${ }^{125} \mathrm{Te}$ $\left\{{ }^{1} \mathrm{H}\right\}$ NMR spectrum at $107 \mathrm{ppm}$. A minor peak at $230 \mathrm{ppm}$ was identified as a small amount of $\mathrm{Te}^{n} \mathrm{Bu}_{2}$, peaks corresponding to which could also be discerned as minor features in the ${ }^{1} \mathrm{H}$ NMR spectrum. Attempted purification by distillation resulted in decomposition of the majority of the compound. The crude product was used for all CVD experiments described below, with no obvious detriment arising from the presence of the minor telluroether impurity. Though sensitive to both atmosphere and temperature (an insoluble dark brown substance forms upon air exposure or storage over days at room temperature), $\operatorname{MeSb}\left(\mathrm{Te}^{n} \mathrm{Bu}\right)_{2}$ is stable over periods of months

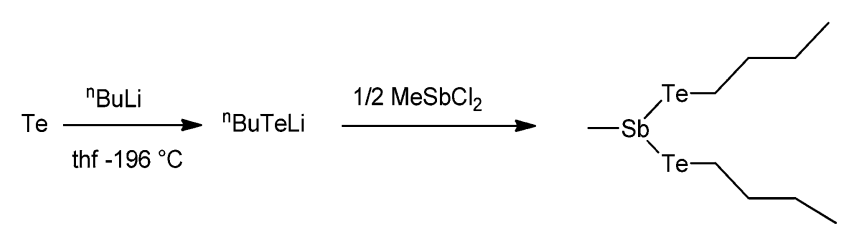

Scheme 2 Synthesis of $\mathrm{MeSb}\left(\mathrm{Te}^{n} \mathrm{Bu}\right)_{2}$. 
when stored under $\mathrm{N}_{2}$ at $-18{ }^{\circ} \mathrm{C}$. Related compounds, $\mathrm{RSb}\left(\mathrm{TeR}^{\prime}\right)_{2}$, have been prepared previously by oxidative addition of cyclic or polymeric $(\mathrm{RSb})_{n}$ across diorganoditellurides, $\mathrm{R}^{\prime} \mathrm{TeTeR}^{\prime}{ }^{25,30,31}$ In some cases this reaction was reported to be reversible in solution, though we found no evidence for the formation of ${ }^{n} \mathrm{BuTeTe}{ }^{n} \mathrm{Bu}$ from solutions of $\mathrm{MeSb}\left(\mathrm{Te}{ }^{n} \mathrm{Bu}\right)_{2} \cdot{ }^{30}$ The compound $\mathrm{MeSb}\left(\mathrm{Te}^{n} \mathrm{Bu}\right)_{2}$ is somewhat thermochromic, appearing as a bright red oil at room temperature, but reversibly darkening to a black-brown solid below $\sim 0{ }^{\circ} \mathrm{C}$. Thermochromism has also been reported for related tellurostibines, $\mathrm{R}_{2} \mathrm{SbTeMe}(\mathrm{R}=\mathrm{Me}, \mathrm{Et}){ }^{32}$

\section{Materials deposition and characterisation}

$\mathbf{S b}_{2} \mathbf{T e}_{3}$ thin films. $\mathrm{MeSb}\left(\mathrm{Te}{ }^{n} \mathrm{Bu}\right)_{2}$ is an efficient precursor for the deposition of $\mathrm{Sb}_{2} \mathrm{Te}_{3}$ by LPCVD. Thermogravimetric analysis (TGA) under a flowing argon atmosphere showed onset of a sudden mass loss $(64 \%)$ at around $100{ }^{\circ} \mathrm{C}$, thought to correspond to evaporation, with no further loss of mass until $600^{\circ} \mathrm{C}$ where a gradual mass decrease begins, probably corresponding to a slow decomposition at high temperature (Fig. S1, ESI $\dagger$ ). During the CVD process $\mathrm{MeSb}\left(\mathrm{Te}^{n} \mathrm{Bu}\right)_{2}$ is seen to evaporate cleanly upon heating under vacuum, and thin, silver coloured films are deposited across substrates heated at temperatures between 300 and $450{ }^{\circ} \mathrm{C}$. SEM images demonstrate that these films are comprised of hexagonal crystallites (Fig. 1 and S2 ESI $\dagger$ ), while EDX confirms that $\mathrm{Sb}$ and Te are present (Fig. S3 ESI†).

The peaks for these elements overlap in the EDX spectrum; quantitative WDX calibrated against elemental standards gives $\mathrm{Sb}: \mathrm{Te}=41.9: 58.1$, which is in close agreement with the expected value of $40: 60$. No peak corresponding to $C$ was identified in the EDX analysis, and combustion analysis performed on $\mathrm{Sb}_{2} \mathrm{Te}_{3}$ powder separated from the substrate gave a C content of $0.74 \%$. When deposition occurs onto fused silica substrates, good coverage is observed over up to 7 tiles (placed in a heated zone between $1 \mathrm{~cm}$ and $14 \mathrm{~cm}$ from the precursor). In our system, proximity to the precursor and precise substrate temperature are inseparably correlated, with tiles furthest from the precursor occupying the hottest zone of the tube furnace (Fig. 2).

Films deposited onto fused silica substrates positioned in this hotter zone $\left(450{ }^{\circ} \mathrm{C}\right)$ (a) are flattest, with SEM images showing the hexagonal faces of many of the $\mathrm{Sb}_{2} \mathrm{Te}_{3}$ crystallites lying parallel to the substrate surface (Fig. 1a). In contrast, films
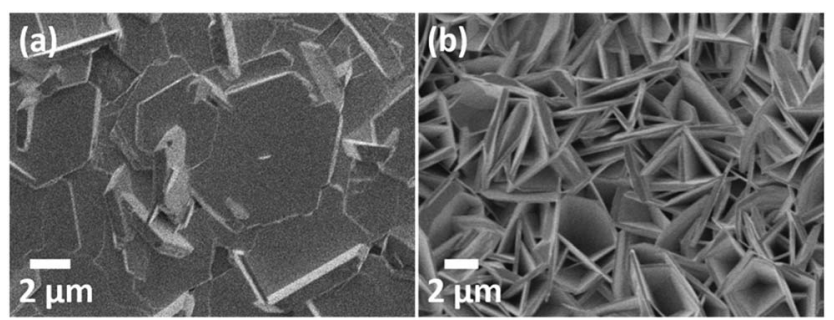

Fig. $1 \mathrm{SEM}$ images of $\mathrm{Sb}_{2} \mathrm{Te}_{3}$ films deposited by CVD onto fused $\mathrm{SiO}_{2}$ substrates; tile (a) in hotter zone; tile (b) in cooler zone.

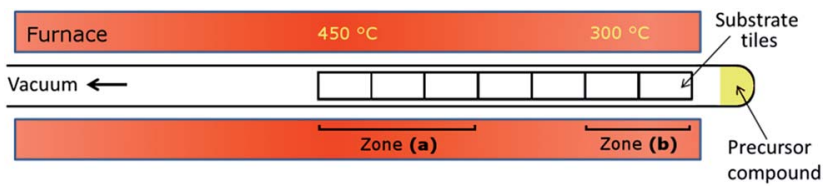

Fig. 2 Schematic of LPCVD reactor with positions of zones (a) and (b) indicated.

deposited in the cooler zone (around $300^{\circ} \mathrm{C}$ ) closer to the source of precursor (b) are roughest, with SEM showing interpenetrating crystallites standing on end with their hexagonal faces approximately perpendicular to the surface (Fig. 1b). This disparity is observed regardless of quantity of precursor or deposition time.

Symmetric $(\theta-2 \theta)$ X-ray diffraction (XRD) patterns of these films show the same single phase of $\mathrm{Sb}_{2} \mathrm{Te}_{3}(R \overline{3} \mathrm{mh})$, with peak positions that correspond well with literature values (Fig. 3, see ESI $\dagger$ for lattice parameters). ${ }^{33}$ However, there are marked differences in the intensities of the peaks for films (a) and (b) in comparison with one another and with the literature pattern for bulk $\mathrm{Sb}_{2} \mathrm{Te}_{3}$.

Pole figures were collected on key reflections for both films, confirming that the disparities in intensity are due to preferred orientation of the crystallites. The symmetric XRD pattern (Fig. 3a) of film (a), which appears flatter by SEM, shows a significant enhancement of the $00 \mathrm{l}$ reflections. A pole figure at the $2 \theta$ position of the 0015 reflection $\left(2 \theta=44.7^{\circ}\right)$ shows a sharp maximum at $\alpha=90^{\circ}$ (Fig. 4.1), whereas that for the 1010 reflection $\left(2 \theta=38.3^{\circ}\right)$ has a sharp ring at $51^{\circ}$ (Fig. 4.2), observations which are commensurate with a $\left\langle\begin{array}{llll}0 & 0 & 1\end{array}\right\rangle$ fibre texture, in which the $c$-axes of the crystallites are oriented perpendicular to

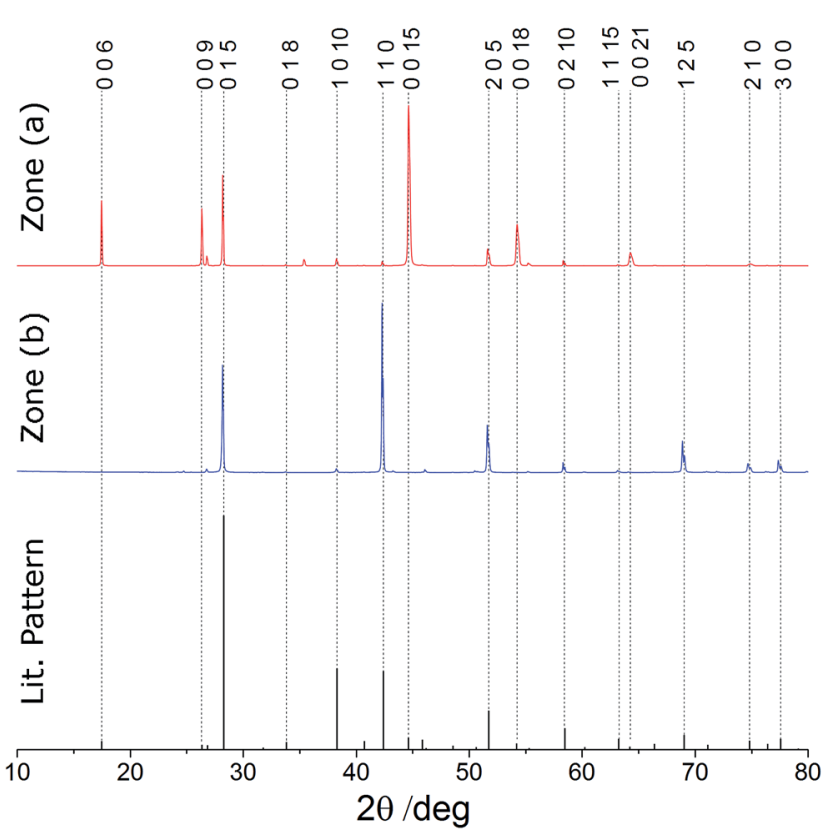

Fig. $3 \theta-2 \theta$ XRD data for $\mathrm{Sb}_{2} \mathrm{Te}_{3}$ deposited by CVD onto fused $\mathrm{SiO}_{2}$ substrates in zone (a) and zone (b); database pattern for $\mathrm{Sb}_{2} \mathrm{Te}_{3}$ from ref. 33. Indices shown above. 
the substrate and the hexagonal ( $a$ and $b$ ) faces of each plate lie flat against the surface (calculated values for $\alpha$ in $\left\langle\begin{array}{lll}0 & 0 & 1\end{array}\right\rangle$ orientation: $0015 \alpha=90^{\circ}$; $1010 \alpha=50.5^{\circ}$ ).

In contrast, the symmetric XRD pattern for film (b) shows a significant enhancement of the 110 reflection and a corresponding suppression of the $00 \mathrm{l}$ reflections, with a pole figure on the 110 reflection $\left(2 \theta=42.3^{\circ}\right)$ this time showing a peak at $90^{\circ}$ (Fig. 4.3), whereas the ring in the pole figure for the 1010 refection is now seen at around $29^{\circ}$ (Fig. 4.4). This is evidence that the crystallites in film (b) have $\left\langle\begin{array}{llll}1 & 1 & 0\end{array}\right)$ preferred orientation, opposite to that seen in film (a), with the $c$-axis parallel to the surface of the substrate (calculated values for $\alpha$ in $\langle 1 \quad 1$ $0\rangle$ orientation: $110, \alpha=90^{\circ} ; 1010, \alpha=29.5^{\circ}$ ), in accord with observations from the SEM images of hexagonal platelets standing on end. The broader peak shapes in the pole figures of film (b) suggest that the degree of orientation is not as high as indicated by the very sharp peaks in those of film (a).

In order to provide a direct comparison for patterned substrates (vide infra), films were also deposited onto substrates
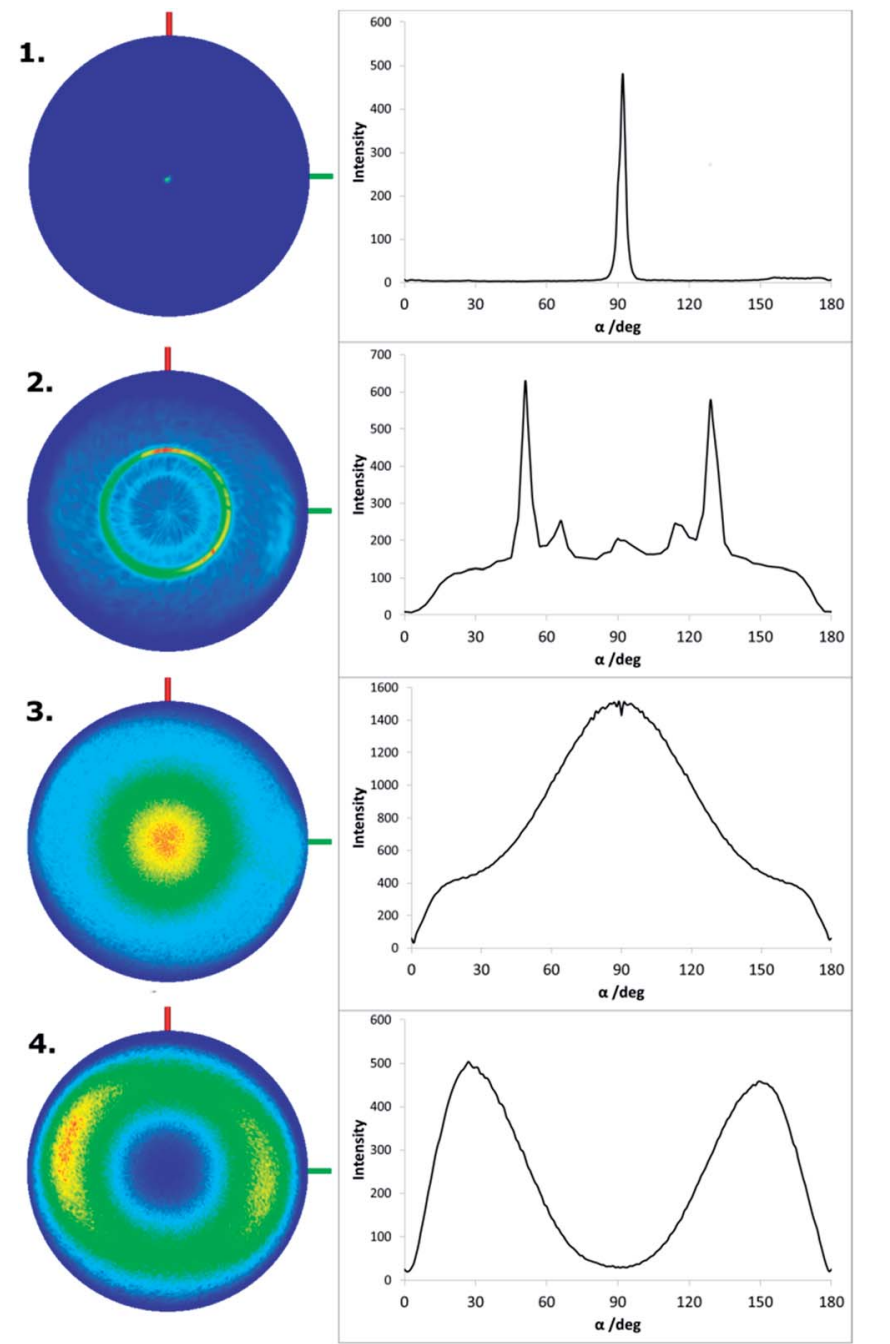

Fig. 4 3D pole figure projections with cut lines: 1. tile (a), 00 15; 2. tile (a) 10 10; 3. tile (b) 110 ; 4. tile (b) 1010 . manufactured by coating a $1 \mu \mathrm{m}$ thick layer of silica onto a silicon wafer by physical vapour deposition (henceforth referred to as 'PVD silica' substrates). Under identical deposition conditions these films had somewhat patchier coverage than those deposited onto fused silica, and SEM images show that they have yet a different morphology, now comprising stacks of thin hexagonal plates (Fig. 5).

The XRD pattern demonstrates the same crystalline phase as those deposited onto fused silica (Fig. S4 ESI $\dagger$ ), with an enhancement of the $00 \mathrm{l}$ peaks, suggesting that the majority of the crystals have their $c$-axes oriented at $90^{\circ}$ to the substrate, including those substrates deposited in zone (a). It would appear that variation in substrate texture or surface termination can appreciably affect the morphology of these deposits onto substrates which are otherwise chemically almost identical. This ability to control crystallite orientation could be highly advantageous for thermoelectric applications, providing an effective way to optimise anisotropic thermal and electrical parameters.

Cross-sectional images were obtained by snapping the tiles after deposition. The film thickness was found to be around 2.2 $\mu \mathrm{m}$, with layered stacks of crystallites visible side on (Fig. 5).

Raman measurements on these thin films reveal three main peaks positioned at 120, 138, and $165 \mathrm{~cm}^{-1}$, respectively (Fig. 6). These are in good agreement with the $\mathrm{E}_{2 \mathrm{~g}}, \mathrm{~A}_{2 \mathrm{u}}$ and $\mathrm{A}_{1 \mathrm{~g}}$ vibration modes of $\mathrm{Sb}_{2} \mathrm{Te}_{3}$ previously reported. ${ }^{34}$

The electronic and thermal properties of the $\mathrm{Sb}_{2} \mathrm{Te}_{3}$ thin films were also investigated. Hall effect measurements show the deposited $\mathrm{Sb}_{2} \mathrm{Te}_{3}$ to be p-type semiconductor with a charge carrier density of $p=4.73 \times 10^{19} \mathrm{~cm}^{-3}$. A charge carrier mobility of $\mu=138 \mathrm{~cm}^{2} \mathrm{~V}^{-1} \mathrm{~S}^{-1}$ was measured, yielding an electrical conductivity of $\sigma=1010 \mathrm{~S} \mathrm{~cm}^{-1}$. The Seebeck coefficient of the material (deposited in zone (b)) was measured to be $90 \mu \mathrm{V} \mathrm{K}^{-1}$. These values are comparable with $\mathrm{Sb}_{2} \mathrm{Te}_{3}$ deposited from other techniques such as molecular beam epitaxy ${ }^{35}$ and atomic layer deposition, ${ }^{36}$ although lower than the values obtained for perfectly stoichiometric $\mathrm{Sb}_{2} \mathrm{Te}_{3}$ deposited at low temperature. ${ }^{37}$ These results suggest that the material deposited by CVD is of quality suitable for thermoelectric and microelectronic applications.

$\mathbf{S b}_{2} \mathbf{T e}_{3}$ arrays. The substrate dependence of these depositions was further investigated competitively by using patterned substrates manufactured by photolithography, consisting of a silicon wafer, surface coated by PVD with a layer of TiN and
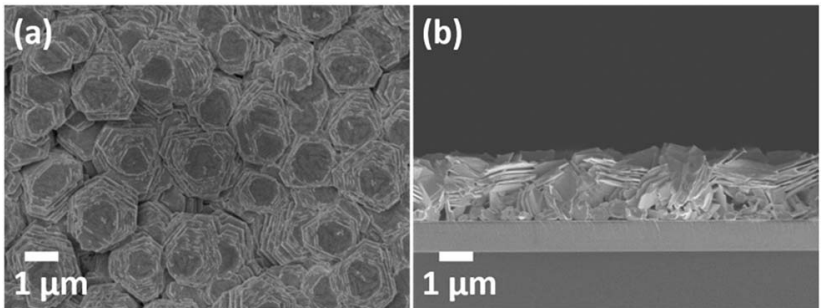

Fig. 5 Top down (left) and cross sectional (right) SEM images of $\mathrm{Sb}_{2} \mathrm{Te}_{3}$ film deposited onto PVD silica substrates. 


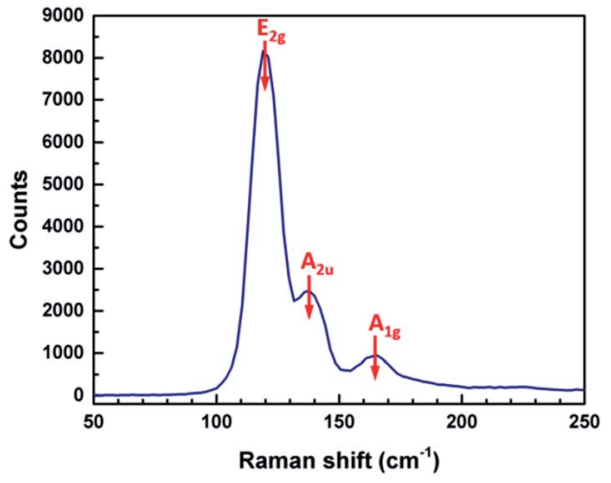

Fig. 6 Raman spectrum of $\mathrm{Sb}_{2} \mathrm{Te}_{3}$ thin film.

subsequently a layer of silica which is back-etched after lithography to reveal TiN areas (henceforth referred to as 'patterned substrates'). Using patterned substrates has previously allowed substrate selective CVD of patterned arrays of a number of metal chalcogenides using chalcogenoether coordination complexes of metal halides as single source precursors. ${ }^{19-21}$ When $\mathrm{MeSb}\left(\mathrm{Te}^{n} \mathrm{Bu}\right)_{2}$ is used in CVD in conjunction with patterned substrates, highly selective deposition is observed for substrates in zone (a). SEM images show that deposition occurs exclusively onto the exposed TiN areas of the substrates, with the silica surface remaining bare (Fig. 7).

Patterns of squares, circles and trenches with dimensions between $100 \mu \mathrm{m}$ and $1 \mu \mathrm{m}$ were filled in this way. EDX mapping of $70-100 \mu \mathrm{m}$ arrays confirms that $\mathrm{Sb}$ and Te are confined to the TiN areas of the pattern, surrounded by uncoated silica surface (Fig. 8). By controlling the quantity of precursor, the thickness of these deposits can be varied from those which protrude significantly from the surrounding silica (Fig. 7a), to very thin layers of crystals which lie flat on the base of the TiN wells (Fig. 7b). This type of substrate selectivity is very unusual for CVD methods, having previously only been observed using coordination complexes of chalcogenoethers as SSPs. The ability to achieve these levels of control in this system highlights the power of using SSPs in an LPCVD framework.

$\mathbf{S b}_{2} \mathrm{Se}_{3}$ thin films. As discussed above, $\mathrm{MeSb}\left(\mathrm{Se}^{n} \mathrm{Bu}\right)_{2}$ was found to be an effective precursor for the deposition of $\mathrm{Sb}_{2} \mathrm{Se}_{3}$ by CVD. SEM images show that films deposited onto PVD silica substrates are composed of rod-like crystallites (Fig. 9).

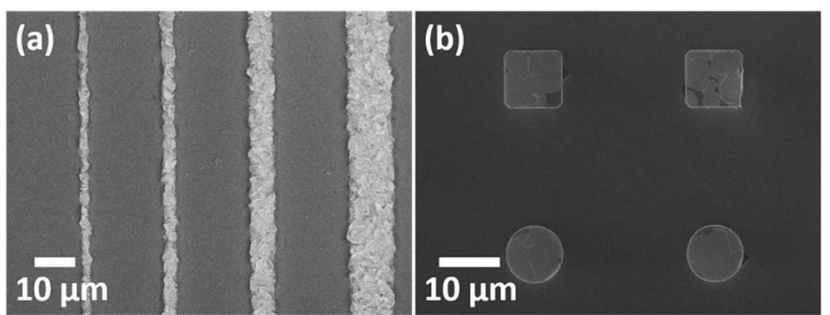

Fig. $7 \mathrm{SEM}$ images of patterned deposits of $\mathrm{Sb}_{2} \mathrm{Te}_{3}$; (a) well filled trenches. (b) Sparingly filled pattern.

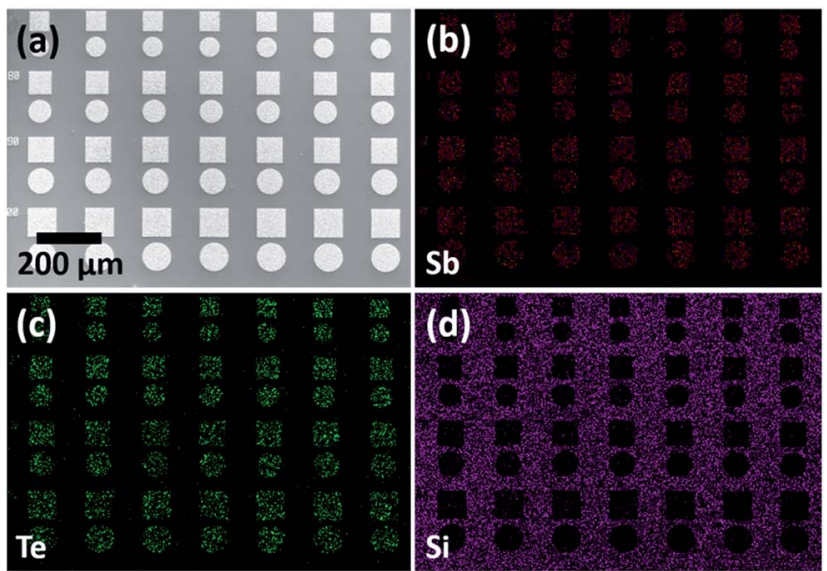

Fig. 8 (a) SEM image of $\mathrm{Sb}_{2} \mathrm{Te}_{3}$ array; (b) EDX mapping of $\mathrm{Sb}$ (red); (c) Te (green); (d) Si (magenta).

EDX gives a mean $\mathrm{Se} / \mathrm{Sb}$ ratio of 1.46 , close to the expected value of 1.50 (Fig. S3 ESI†). Grazing incidence powder X-ray diffraction matches the literature pattern for orthorhombic $\mathrm{Sb}_{2} \mathrm{Se}_{3}$ with small variations in peak intensity likely due to a limited degree of preferred orientation (Fig. 10). ${ }^{38}$

The Raman spectrum of the $\mathrm{Sb}_{2} \mathrm{Se}_{3}$ thin films was collected (Fig. 11); this is in good agreement with previously reported data. ${ }^{39}$ The main feature at about $190 \mathrm{~cm}^{-1}$ is the characteristic of the Sb-Se stretching mode of the $\mathrm{SbSe}_{3 / 2}$-pyramids. ${ }^{40}$ The peak at $\sim 150 \mathrm{~cm}^{-1}$ can be associated to the $\mathrm{Sb}-\mathrm{Sb}$ bonds and the vibration at around $125 \mathrm{~cm}^{-1}$ is related to the Se-Se bonds. These three peaks can be assigned as the $\mathrm{A}_{1 \mathrm{~g}}^{2}, \mathrm{~A}_{2 \mathrm{u}}^{2}$, and $\mathrm{E}_{\mathrm{g}}^{2}$ vibration mode, respectively. ${ }^{41}$

Hall effect measurements conducted on the $\mathrm{Sb}_{2} \mathrm{Se}_{3}$ films reveal a conductivity of $\sigma=1.14 \times 10^{-6} \mathrm{~S} \mathrm{~cm}^{-1}$. The low value of conductivity matches well with the wide band gap (1.1 eV) reported for $\mathrm{Sb}_{2} \mathrm{Se}_{3}{ }^{42}$ These measurements also confirmed the $\mathrm{Sb}_{2} \mathrm{Se}_{3}$ to be a p-type semiconductor with carrier density and carrier mobility of $5.75 \times 10^{11} \mathrm{~cm}^{-3}$ and $14.2 \mathrm{~cm}^{2} \mathrm{~V}^{-1} \mathrm{~S}^{-1}$, respectively. However, these films were found to be quite brittle and poorly adhered to the substrate, and hence reliable measurement of the Seebeck coefficient was not possible. It is clear from cross-sectional SEM images (Fig. 9b) that the films are composed of loosely packed large ( $\sim 5 \mu \mathrm{m}$ long) individual rod-shaped crystallites, leading to a film of low density and with non-uniform thickness.

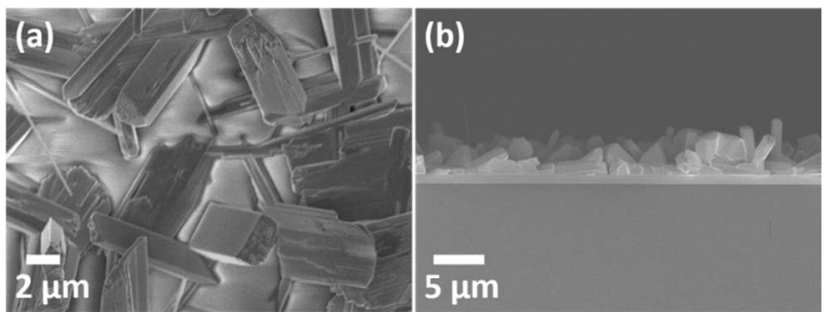

Fig. 9 (a) Top down and (b) cross sectional SEM images of $\mathrm{Sb}_{2} \mathrm{Se}_{3}$ film deposited onto PVD silica substrates. 


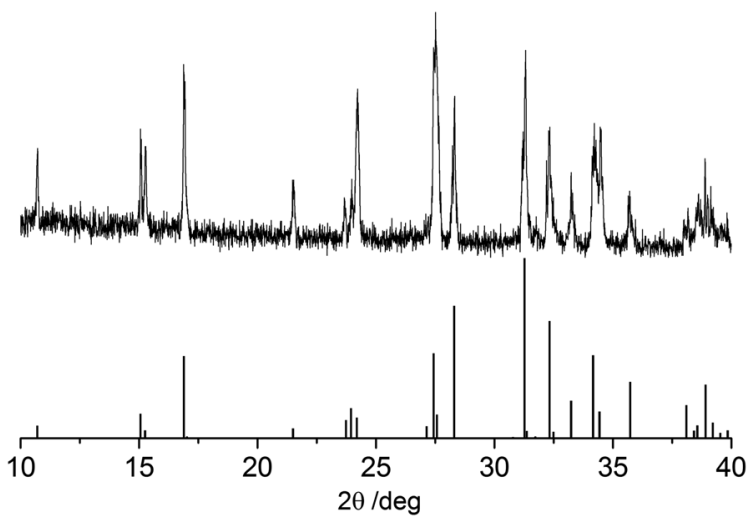

Fig. 10 Grazing incidence (2 $\theta) \mathrm{X}$-ray diffraction pattern of $\mathrm{Sb}_{2} \mathrm{Se}_{3}$ film (top), literature pattern for $\mathrm{Sb}_{2} \mathrm{Se}_{3}$ from ref. 38 (bottom).

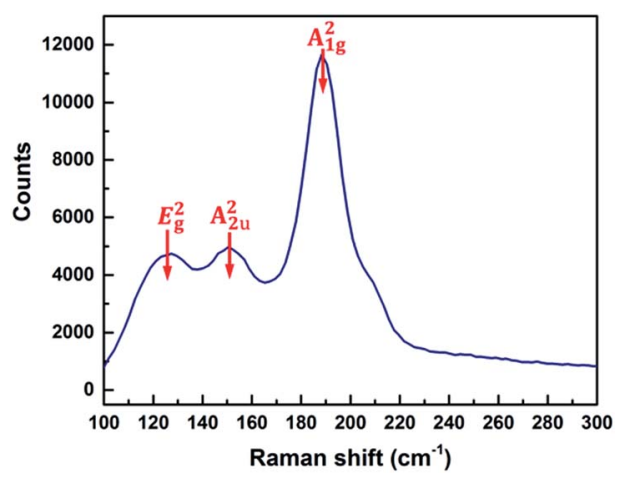

Fig. 11 Raman spectrum of $\mathrm{Sb}_{2} \mathrm{Se}_{3}$ thin film.

Substrate effects were once again probed by the use of patterned substrates. Marked differences were observed in the morphology of $\mathrm{Sb}_{2} \mathrm{Se}_{3}$ deposited onto TiN areas of the substrates compared to silica areas (Fig. 12), though substrate selectivity comparable to that seen for $\mathrm{Sb}_{2} \mathrm{Te}_{3}$ was not observed. Instead, even under precursor limited conditions, some deposition occurs on both surfaces; on $\mathrm{SiO}_{2}$ this consists of separated clusters of $\mathrm{Sb}_{2} \mathrm{Se}_{3}$ crystallites, whereas on TiN a continuous thin film of smaller crystallites is observed. This suggests that TiN is a promising material on which to deposit more uniform and well adhered thin films of $\mathrm{Sb}_{2} \mathrm{Se}_{3}$.

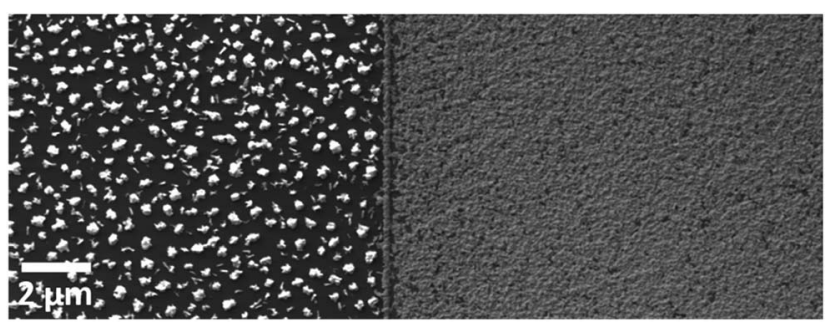

Fig. $12 \mathrm{Sb}_{2} \mathrm{Se}_{3}$ deposited across a boundary between $\mathrm{SiO}_{2}$ area (left) and TiN area (right) of patterned substrate.

\section{Experimental}

\section{Precursor preparation and characterisation}

Reactions were conducted using Schlenk, vacuum line and glove-box techniques under a dry nitrogen atmosphere. The reagents were stored and manipulated using a glove box. Hexane was distilled from Na wire; THF was distilled from $\mathrm{Na}$ / benzophenone ketyl. ${ }^{n} \mathrm{BuLi}$ (1.6 M solution in hexanes) was obtained from Acros and used as received. $\mathrm{SbCl}_{3}$ was obtained from Sigma-Aldrich and sublimed in vacuo prior to use. $\mathrm{Me}_{2^{-}}$ $\mathrm{SbCl}$ and $\mathrm{MeSbCl}_{2}$ were prepared by treatment of $\mathrm{Me}_{2} \mathrm{SbPh}$ and $\mathrm{MeSbPh}_{2}$ with $\mathrm{HCl}$, according to the literature method. ${ }^{43}$ The ${ }^{1} \mathrm{H},{ }^{13} \mathrm{C}\left\{{ }^{1} \mathrm{H}\right\},{ }^{77} \mathrm{Se}\left\{{ }^{1} \mathrm{H}\right\}$ and ${ }^{125} \mathrm{Te}\left\{{ }^{1} \mathrm{H}\right\}$ NMR spectra were recorded at $298 \mathrm{~K}$ in $\mathrm{CDCl}_{3}$ using a Bruker DPX400 spectrometer and referenced to the residual protio-solvent resonance, neat $\mathrm{SeMe}_{2}$ and neat $\mathrm{TeMe}_{2}$ respectively. Microanalyses were undertaken by Medac Ltd and London Metropoliton University. Thermogravimetric analyses (TGA) used a Mettler Toledo TGA/SDTA851e analyser under a flow of Ar at $65 \mathrm{~mL} \mathrm{~min}{ }^{-1}$, contained within a dry, $\mathrm{N}_{2}$-purged glove box. The temperature was increased at a rate of $10{ }^{\circ} \mathrm{C} \mathrm{min}^{-1}$.

$\mathbf{M e}_{2} \mathrm{SbSe}^{n} \mathrm{Bu}$. A suspension of finely ground selenium $(0.37 \mathrm{~g}$, $4.8 \mathrm{mmol}$ ) in THF ( $40 \mathrm{~mL}$ ) was cooled in a bath of liquid $\mathrm{N}_{2}$ until frozen. ${ }^{n} \mathrm{BuLi}$ ( $3.0 \mathrm{~mL}$ of $1.6 \mathrm{M}$ in hexanes, $4.8 \mathrm{mmol}$ ) was added, and the mixture allowed to warm to room temperature, resulting in a clear, pale yellow solution. A solution of $\mathrm{SbMe}_{2} \mathrm{Cl}(0.9 \mathrm{~g}$, $4.8 \mathrm{mmol})$ in THF $(2 \mathrm{~mL})$ was added causing an immediate intensification of the solution's colour to bright yellow. The reaction mixture was stirred for one hour, then the volatiles removed in vacuo to yield some pale solid and yellow oil, which were extracted with hexane $(20 \mathrm{~mL})$. The solution was filtered and the remaining solids washed with hexane $(10 \mathrm{~mL})$. The combined organics were concentrated in vacuo to give the product as a yellow oil $(0.9 \mathrm{~g}, 65 \%) .{ }^{1} \mathrm{H}$ NMR $\left(\mathrm{CDCl}_{3}\right)$ : $0.92(\mathrm{t}$, [3H], $\left.\mathrm{CH}_{3}\right), 1.23\left(\mathrm{~s},[6 \mathrm{H}], \mathrm{CH}_{3} \mathrm{Sb}\right), 1.42\left(\mathrm{q},[2 \mathrm{H}], \mathrm{CH}_{2}\right), 1.68(\mathrm{~m}$, $\left.[2 \mathrm{H}], \mathrm{CH}_{2}\right), 2.72\left(\mathrm{t},[2 \mathrm{H}], \mathrm{CH}_{2} \mathrm{Se}\right) .{ }^{13} \mathrm{C}\left\{{ }^{1} \mathrm{H}\right\} \mathrm{NMR}\left(\mathrm{CDCl}_{3}\right):-0.2(\mathrm{br}$, MeSb), 13.5, 21.2, 22.9, $36.2\left({ }^{n} \mathrm{Bu}\right) .{ }^{77} \mathrm{Se}\left\{{ }^{1} \mathrm{H}\right\} \operatorname{NMR}\left(\mathrm{CH}_{2} \mathrm{Cl}_{2} /\right.$ $\left.\mathrm{CDCl}_{3}\right):-17.6$.

$\operatorname{MeSb}\left(\mathrm{Se}^{n} \mathbf{B u}\right)_{2}$. A suspension of finely ground selenium (0.99 $\mathrm{g}, 12.8 \mathrm{mmol})$ in THF $(80 \mathrm{~mL})$ was cooled in a bath of liquid $\mathrm{N}_{2}$ until frozen. ${ }^{n}$ BuLi ( $8.0 \mathrm{~mL}$ of $1.6 \mathrm{M}$ in hexanes, $12.8 \mathrm{mmol}$ ) was added, and the mixture allowed to warm to room temperature, resulting in a clear, pale yellow solution. A solution of $\mathrm{SbMeCl}_{2}$ $(1.33 \mathrm{~g}, 6.4 \mathrm{mmol})$ in THF $(8 \mathrm{~mL})$ was added causing an immediate orange colour which then faded to yellow. The reaction mixture was stirred for one hour, then the volatiles removed in vacuo to yield some pale solid and yellow oil, which were extracted with hexane $(15 \mathrm{~mL})$. The solution was filtered and concentrated in vacuo to give the product as a yellow oil (1.5 g, 57\%). ${ }^{1} \mathrm{H} \mathrm{NMR}\left(\mathrm{CDCl}_{3}\right): 0.93\left(\mathrm{t},[6 \mathrm{H}], \mathrm{CH}_{3}\right), 1.44\left(\mathrm{q},[4 \mathrm{H}], \mathrm{CH}_{2}\right)$, $1.55\left(\mathrm{~s},[3 \mathrm{H}], \mathrm{CH}_{3} \mathrm{Sb}\right), 1.73\left(\mathrm{~m},[4 \mathrm{H}], \mathrm{CH}_{2}\right), 2.87\left(\mathrm{t},[4 \mathrm{H}], \mathrm{CH}_{2} \mathrm{Se}\right)$. ${ }^{13} \mathrm{C}\left\{{ }^{1} \mathrm{H}\right\}$ NMR $\left(\mathrm{CDCl}_{3}\right): 1.92$ (br, MeSb), 13.5, 22.8, 22.9, 35.7 $\left({ }^{n} \mathrm{Bu}\right) .{ }^{77} \mathrm{Se}\left\{{ }^{1} \mathrm{H}\right\}$ NMR $\left(\mathrm{CH}_{2} \mathrm{Cl}_{2} / \mathrm{CDCl}_{3}\right):$ 34.1. Calculated for $\mathrm{C}_{9} \mathrm{H}_{21} \mathrm{Sb}_{1} \mathrm{Se}_{2}$ : C, 26.4; $\mathrm{H}, 5.2$; found: C, 27.6, $\mathrm{H}, 6.1 \%$ (note that the compound is a very air-sensitive and thermally-sensitive oil, making both removal of trace solvent and out-sourced 
analytical measurements very challenging. The ${ }^{77} \mathrm{Se}$ NMR spectrum did not reveal any other Se-containing species, and no other species were evident in the ${ }^{1} \mathrm{H}$ NMR spectrum.)

$\mathbf{S b}\left(\mathrm{Se}^{n} \mathrm{Bu}\right)_{3}$. A suspension of finely ground selenium $(2.0 \mathrm{~g}$, $26.3 \mathrm{mmol})$ in THF $(100 \mathrm{~mL})$ was cooled in a bath of liquid $\mathrm{N}_{2}$ until frozen. ${ }^{n} \mathrm{BuLi}(16.4 \mathrm{~mL}$ of $1.6 \mathrm{M}$ in hexanes, $26.3 \mathrm{mmol})$ was added, and the mixture allowed to warm to room temperature, resulting in a clear, pale yellow solution. A solution of $\mathrm{SbCl}_{3}(2.0 \mathrm{~g}, 8.8 \mathrm{mmol})$ in THF $(20 \mathrm{~mL})$ was added causing an immediate dark orange colour which gradually changed to dark yellow. The reaction mixture was stirred for one hour, then the volatiles removed in vacuo to yield some pale solid a yellow oil, which were extracted with hexane $(60 \mathrm{~mL})$. The solution was filtered and the remaining solids washed with hexane $(10 \mathrm{~mL})$. The combined organics were taken down in vacuo to give the product as a yellow oil $(2.8 \mathrm{~g}, 60 \%) .{ }^{1} \mathrm{H} \mathrm{NMR}\left(\mathrm{CDCl}_{3}\right): 0.93(\mathrm{t}$, $\left.[3 \mathrm{H}], \mathrm{CH}_{3}\right), 1.46\left(\mathrm{q},[2 \mathrm{H}], \mathrm{CH}_{2}\right), 1.75\left(\mathrm{~m},[2 \mathrm{H}], \mathrm{CH}_{2}\right), 2.96(\mathrm{t},[2 \mathrm{H}]$, $\left.\mathrm{CH}_{2} \mathrm{Se}\right) .{ }^{13} \mathrm{C}\left\{{ }^{1} \mathrm{H}\right\} \mathrm{NMR}\left(\mathrm{CDCl}_{3}\right): 13.6,22.9,25.3,35.5\left({ }^{n} \mathrm{Bu}\right) .{ }^{77} \mathrm{Se}$ $\left\{{ }^{1} \mathrm{H}\right\} \mathrm{NMR}\left(\mathrm{CH}_{2} \mathrm{Cl}_{2} / \mathrm{CDCl}_{3}\right):$ 45.0.

$\operatorname{MeSb}\left(\mathrm{Te}^{n} \mathrm{Bu}\right)_{2}$. A suspension of finely ground tellurium (1.46 $\mathrm{g}, 11.4 \mathrm{mmol})$ in THF $(80 \mathrm{~mL})$ was cooled in a bath of liquid $\mathrm{N}_{2}$ until frozen. ${ }^{n}$ BuLi (7.13 mL of 1.6 M solution in hexanes, 11.4 mmol) was added and the mixture allowed to warm to $10{ }^{\circ} \mathrm{C}$, resulting in a clear, pale yellow solution, which was cooled again to $-78{ }^{\circ} \mathrm{C}$. A solution of $\mathrm{SbMeCl}_{2}(1.19 \mathrm{~g}, 5.7 \mathrm{mmol})$ in THF (5 $\mathrm{mL}$ ) was added dropwise, giving a deep orange/red solution which was stirred for $30 \mathrm{~min}$. at $-78^{\circ} \mathrm{C}$, then allowed to warm to room temperature. The volatiles were removed in vacuo leaving a dark brown paste, which was extracted with hexane $(60 \mathrm{~mL})$. The resulting deep orange solution was removed from the dark solid residues by filtration and the volatiles removed in vacuo yielding an orange/red oil (2.1 g, 72\%). The NMR spectra showed a small amount of ${ }^{n} \mathrm{Bu}_{2}$ Te in addition to the product, and was unchanged after storage under $\mathrm{N}_{2}$ at $-18{ }^{\circ} \mathrm{C}$, at which temperature it is a brown solid. The colour change seen between the solid and liquid states is significant, but fully reversible. ${ }^{1} \mathrm{H}$ NMR $\left(\mathrm{CDCl}_{3}\right): 0.92\left(\mathrm{t},[6 \mathrm{H}], \mathrm{CH}_{3}\right), 1.42\left(\mathrm{q},[4 \mathrm{H}], \mathrm{CH}_{2}\right), 1.78(\mathrm{~m}$, $\left.[4 \mathrm{H}], \mathrm{CH}_{2}\right), 1.88$ (s, [3H], $\left.\mathrm{CH}_{3} \mathrm{Sb}\right), 2.88$ (t, [4H], $\left.\mathrm{CH}_{2} \mathrm{Te}\right) .{ }^{13} \mathrm{C}\left\{{ }^{1} \mathrm{H}\right\}$ NMR $\left(\mathrm{CDCl}_{3}\right):-8.0$ (br, MeSb), 1.1, 11.0, 22.7, $33.9\left({ }^{n} \mathrm{Bu}\right) .{ }^{125} \mathrm{Te}$ $\left\{{ }^{1} \mathrm{H}\right\}$ NMR $\left(\mathrm{CDCl}_{3}\right):$ 107.4, $\left(230.4, \mathrm{Te}^{n} \mathrm{Bu}_{2}\right)$.

\section{Substrate preparation}

$\begin{array}{llll}\text { PVD } & \mathrm{SiO}_{2} & \text { and photolithographically patterned } \mathrm{TiN} / \mathrm{SiO}_{2}\end{array}$ substrates were prepared as described previously. ${ }^{20,21}$

\section{LPCVD}

In a typical experiment, $5-50 \mathrm{mg}$ of the reagent, followed by the substrate tiles $(0.5 \times 8 \times 20 \mathrm{~mm})$, were loaded into a closed-end silica tube in a glove box. The substrates were positioned end-toend through the heated zone. The tube was set in the furnace such that the precursor was $1.5 \mathrm{~cm}$ away from the edge of the heated zone. The tube was evacuated $(\sim 0.05 \mathrm{~mm} \mathrm{Hg})$, and then the furnace set to $500{ }^{\circ} \mathrm{C}\left(\mathrm{Sb}_{2} \mathrm{Se}_{3}\right)$ or $450{ }^{\circ} \mathrm{C}\left(\mathrm{Sb}_{2} \mathrm{Te}_{3}\right)$. Temperature profiling demonstrates that there is a temperature gradient along the furnace with the central zone reaching the set temperature and each end being cooler by up to $150{ }^{\circ} \mathrm{C}$. After
$40 \mathrm{~min}$. the tube was cooled to room temperature under vacuum, the substrates subsequently being unloaded and handled in air. Thin films were deposited onto substrates in all temperature zones, and were silvery grey in appearance.

\section{Thin film characterisation}

XRD measurements were carried out using a Rigaku Smartlab diffractometer with a $9 \mathrm{~kW} \mathrm{Cu}-\mathrm{K}_{\alpha}$ source, parallel line focus incident beam and a DTex250 1D detector. Raman scattering spectra of the deposited films were measured at room temperature on a Renishaw InVia Micro Raman Spectrometer using a helium-neon laser with a wavelength of $633 \mathrm{~nm}$. The incident laser power was adjusted to $\sim 1 \mathrm{~mW}$ for all samples. SEM was performed using a Zeiss EVO LS 25 with an accelerating voltage of $10 \mathrm{kV}$, and EDX data were obtained with an Oxford INCAx-act $\mathrm{X}$-ray detector. WDX was obtained with a ThermoFisher MagnaRay probe using NiC80 and PET X-ray diffracting crystals. High resolution SEM measurements were carried out with a field emission SEM (Jeol JSM 7500F) at an accelerating voltage of $2 \mathrm{kV}$. Microanalyses were undertaken by Medac Ltd. Hall effect measurements were performed at room temperature on a Nanometrics HL5500PC with a current of $1 \mathrm{~mA}$ under a field of 0.5 Tesla at $300 \mathrm{~K}$. The Seebeck coefficient was determined using a custom-made Seebeck measurement unit, which was calibrated against a polycrystalline Bi foil reference standard. The measurement accuracy was found to be within $5 \%$ and the system was calibrated using copper-constantan thermocouples and a high precision Keithley DMM 2000/E digital multimeter with $0.1 \%$ accuracy.

\section{Conclusions}

Several new seleno- and tellurostibines have been prepared and screened as single source precursors for LPCVD of $\mathrm{Sb}_{2} \mathrm{E}_{3}(\mathrm{E}=$ $\mathrm{Se}, \mathrm{Te}) ; \mathrm{MeSb}\left(\mathrm{E}^{n} \mathrm{Bu}\right)_{2}$ were identified to be particularly effective for the deposition of highly crystalline thin films of p-type $\mathrm{Sb}_{2} \mathrm{E}_{3}$, leading to very good coverage. Electrical characterisation of the films has revealed their conductivities, carrier densities and mobilities are comparable with those for $\mathrm{Sb}_{2} \mathrm{E}_{3}$ films deposited by MBE or ALD, confirming there are of the quality required for incorporation into functional electronic devices.

Subtle substrate and temperature effects were found to affect the preferred orientation of the crystallites, and were investigated using detailed XRD analysis and SEM imaging. Adjusting these parameters allows control over the orientation of deposited $\mathrm{Sb}_{2} \mathrm{Te}_{3}$ crystallites either parallel or perpendicular to the $\mathrm{SiO}_{2}$ surface. This is an important factor for applications of these materials, for example in thermoelectric devices, where the $\left\langle\begin{array}{lll}1 & 1 & 0\end{array}\right\rangle$ alignment is favoured, as it maximises the anisotropy of the thermoelectric parameters, but is often very difficult to achieve in thin films.

Positional control of $\mathrm{Sb}_{2} \mathrm{Te}_{3}$ growth on the $\mu \mathrm{m}$ scale has also been demonstrated via LPCVD using $\operatorname{MeSb}\left(\mathrm{Te}^{n} \mathrm{Bu}\right)_{2}$. Exploiting the subtle substrate discrimination made possible using this single source precursor, highly regular arrays of $\mathrm{Sb}_{2} \mathrm{Te}_{3}$ crystallites have been deposited into patterned templates. 
Work is ongoing to extend this capability to nano-patterned templates for fabrication of electronic devices.

\section{Acknowledgements}

We thank the EPSRC for support (EP/I010890/1), for provision of the thin film X-ray diffraction instrument (EP/K009877/1 and EP/K00509X/1) and for a Doctoral Prize (S.L.B., EP/P504740/1). We also thank STFC for funding (ST/L003376/1) and Mr A. Clark for help with the WDX measurements.

\section{Notes and references}

1 V. A. Kutasov, L. N. Lukyanova and M. V. Vedernikov, in Thermoelectrics Handbook: Macro to Nano, ed. R. D. Michael, CRC Press, 2006, ch. 37, pp. 37-31 to 37-18.

2 C. J. Vineis, A. Shakouri, A. Majumdar and M. G. Kanatzidis, Adv. Mater., 2010, 22, 3970-3980.

3 R. Venkatasubramanian, E. Siivola, T. Colpitts and B. O'Quinn, Nature, 2001, 413, 597-602.

4 M. Stordeur and W. Heiliger, Phys. Status Solidi B, 1976, 78, K103-K106.

5 D. L. Medlin and G. J. Snyder, Curr. Opin. Colloid Interface Sci., 2009, 14, 226-235.

6 Q. Jiang, H. Yan, J. Khaliq, H. Ning, S. Grasso, K. Simpson and M. J. Reece, J. Mater. Chem. A, 2014, 2, 5785-5790.

7 H. Zhang, C.-X. Liu, X.-L. Qi, X. Dai, Z. Fang and S.-C. Zhang, Nat. Phys., 2009, 5, 438-442.

8 H. Tang, D. Liang, R. L. J. Qiu and X. P. A. Gao, ACS Nano, 2011, 5, 7510-7516.

9 Y. C. Choi, T. N. Mandal, W. S. Yang, Y. H. Lee, S. H. Im, J. H. Noh and S. I. Seok, Angew. Chem., Int. Ed., 2013, 53, 1329-1333.

10 X. Liu, J. Chen, M. Luo, M. Leng, Z. Xia, Y. Zhou, S. Qin, D.-J. Xue, L. Lv, H. Huang, D. Niu and J. Tang, ACS Appl. Mater. Interfaces, 2014, 6, 10687-10695.

11 G. Bendt, S. Zastrow, K. Nielsch, P. S. Mandal, J. SanchezBarriga, O. Rader and S. Schulz, J. Mater. Chem. A, 2014, 2, 8215-8222.

12 M. A. Malik, M. Afzaal and P. O'Brien, Chem. Rev., 2010, 110, 4417-4446.

13 H. J. Gysling, A. A. Wernberg and T. N. Blanton, Chem. Mater., 1992, 4, 900-905.

14 S. S. Garje, D. J. Eisler, J. S. Ritch, M. Afzaal, P. O'Brien and T. Chivers, J. Am. Chem. Soc., 2006, 128, 3120-3121.

15 R. K. Sharma, G. Kedarnath, V. K. Jain, A. Wadawale, M. Nalliath, C. G. S. Pillai and B. Vishwanadh, Dalton Trans., 2010, 39, 8779-8787.

16 R. S. Dickson and K. D. Heazle, J. Organomet. Chem., 1995, 493, 189-197.

17 S. Schulz, S. Heimann, J. Friedrich, M. Engenhorst, G. Schierning and W. Assenmacher, Chem. Mater., 2012, 24, 2228-2234.

18 G. Bendt, S. Schulz, S. Zastrow and K. Nielsch, Chem. Vap. Deposition, 2013, 19, 235-241.
19 S. L. Benjamin, C. H. de Groot, C. Gurnani, A. L. Hector, R. Huang, K. Ignatyev, W. Levason, S. J. Pearce, F. Thomas and G. Reid, Chem. Mater., 2013, 25, 4719-4724.

20 S. L. Benjamin, C. H. de Groot, C. Gurnani, A. L. Hector, R. Huang, E. Koukharenko, W. Levason and G. Reid, J. Mater. Chem. A, 2014, 2, 4865-4869.

21 C. H. de Groot, C. Gurnani, A. L. Hector, R. Huang, M. Jura, W. Levason and G. Reid, Chem. Mater., 2012, 24, 4442-4449.

22 K. George, C. H. de Groot, C. Gurnani, A. L. Hector, R. Huang, M. Jura, W. Levason and G. Reid, Chem. Mater., 2013, 25, 1829-1836.

23 G. Zeni, M. P. Stracke, C. W. Nogueira, A. L. Braga, P. H. Menezes and H. A. Stefani, Org. Lett., 2004, 6, 11351138.

24 A. J. Ashe III and E. G. Ludwig Jr, J. Organomet. Chem., 1986, 308, 289-296.

25 H. J. Breunig, S. Gülec and R. Kaller, Phosphorus, Sulfur Silicon Relat. Elem., 1992, 67, 33-38.

26 A. Haaland, H. P. Verne, H. V. Volden, H. J. Breunig and S. Gulec, Z. Naturforsch., B: Chem. Sci., 1993, 48, 1065-1068.

27 H. J. Breunig and S. Guelec, Z. Naturforsch., B: Chem. Sci., 1988, 43, 998-1002.

28 H. J. Breunig, S. Guelec, B. Krebs and M. Dartmann, Z. Naturforsch., B: Chem. Sci., 1989, 44, 1351-1354.

29 G. Zeni, H. B. Formiga and J. V. Comasseto, Tetrahedron Lett., 2000, 41, 1311-1313.

30 P. Šimon, R. Jambor, A. Rưžička and L. Dostál, Organometallics, 2013, 32, 239-248.

31 A. Silvestru, H. J. Breunig, K. H. Ebert and R. Kaller, J. Organomet. Chem., 1995, 501, 117-121.

32 H. J. Breunig, Phosphorus Sulfur Relat. Elem., 1988, 38, 97102.

33 T. L. Anderson and H. B. Krause, Acta Crystallogr., Sect. B: Struct. Crystallogr. Cryst. Chem., 1974, 30, 1307-1310.

34 G. C. Sosso, S. Caravati and M. Bernasconi, J. Phys.: Condens. Matter, 2009, 21, 095410.

35 N. Peranio, M. Winkler, Z. Aabdin, J. König, H. Böttner and O. Eibl, Phys. Status Solidi A, 2012, 209, 289-293.

36 S. Zastrow, J. Gooth, T. Boehnert, S. Heiderich, W. Toellner, S. Heimann, S. Schulz and K. Nielsch, Semicond. Sci. Technol., 2013, 28, 035010.

37 P. Fan, Z.-H. Zheng, G.-X. Liang, D.-P. Zhang and X.-M. Cai, J. Alloys Compd., 2010, 505, 278-280.

38 N. W. Tideswell, F. H. Kruse and J. D. McCullough, Acta Crystallogr., 1957, 10, 99-102.

39 Z. G. Ivanova, E. Cernoskova, V. S. Vassilev and S. V. Boycheva, Mater. Lett., 2003, 57, 1025-1028.

40 J. Wang, Z. Deng and Y. Li, Mater. Res. Bull., 2002, 37, 495502.

41 A. Bera, K. Pal, D. V. S. Muthu, S. Sen, P. Guptasarma, U. V. Waghmare and A. K. Sood, Phys. Rev. Lett., 2013, 110, 107401.

42 S. Messina, M. T. S. Nair and P. K. Nair, J. Electrochem. Soc., 2009, 156, Н327-H332.

43 H. J. Breunig, H. Althaus, R. Rosler and E. Lork, Z. Anorg. Allg. Chem., 2000, 626, 1137-1140. 